\title{
The environmentally safe method of control of broomrape (Orobanche cumana Wallr.) parasitizing on sunflower
}

\author{
Evgeniy Strelnikov ${ }^{1}$, Tatiana Antonova ${ }^{1 *}$, Lyudmila Gorlova ${ }^{1}$, and Victoria Trubina ${ }^{1}$ \\ ${ }^{1}$ Pustovoit All-Russian Research Institute of Oil Crops, Krasnodar, 350038, Russia
}

\begin{abstract}
Orobanche cumana Wallr., an obligate parasite of sunflower, is widely spread in most countries cultivating this crop. It is one of the main factors limiting the cultivation of sunflower. The aim of our research was to determine the influence of application of oil crops (Brassicaceae) green manures on the sunflower infection with broomrape under greenhouse conditions. We used the green mass of white, black, common mustard and winter rapeseed as a green manure. We added the crushed green mass of these crops $(62.5-90.0 \mathrm{~g})$ to vessels with a soil-sand mixture mixed with broomrape seeds. After 15 days, we sowed the seeds of sunflower variety susceptible to all races of broomrape. We did not add the green manures in the control. The green manure of white mustard (variety Ruslana) showed the highest percentage of decrease in the infection degree $-44.7 \%$. The common mustard (Yunona) and black mustard (Niagara) reduced the infection by 25.9 and $27.0 \%$, respectively, the rapeseed (Tavrion) - by $24 \%$. We recommend using the green manures of these crops to reduce infection of sunflower crops with broomrape and as an environmentally safe method of clearing the field from its seeds.
\end{abstract}

\section{Introduction}

Sunflower (Helianthus annuus L.) is a valuable oil crop that provides for the needs in vegetable oil not only in the Russian Federation but also in many other countries of the world. High profitability of sunflower cultivation makes it attractive for intensive cultivation. In the Russian Federation, the crop acreage occupied by sunflower is increasing each year. For instance, over the past 10 years the acreage has increased by $37.2 \%$. In 2019, according to the Russian Federal State Statistics Service, the crop acreage of sunflower in farms of all categories amounted to 8505.3 thousand ha.

One of the main factors limiting sunflower production in the southern regions of the Russian Federation is the broomrape parasitic plant (Orobanche cumana Wallr.) [1]. This weed parasitic plant also affects sunflower in many other countries of the world cultivating this crop. Broomrape is one of the main factors that significantly reduces the yield and worsens the seed quality [2-8]. O.cumana is an obligate parasite that belongs to the higher

\footnotetext{
"Corresponding author: antonova-ts@mail.ru
} 
flowering plants from the Orobanchaceae family. Broomrape plants do not have their own roots and leaves; they are completely devoid of chlorophyll.

The broomrape seedling grows into the sunflower root and feeds at its expense, developing the tubercle outside the root that is rich in nutrients. One or more apical points are formed in the tubercle, from which one or more stems grow. Under favorable conditions, the stems in $O$. cumana can reach a height of about $1 \mathrm{~m}$ and develop up to 100 flowers [9]. The upper part of a stem with flowers of $O$. cumana represents a loose spikeshaped inflorescence.

In each flower, a fruit ripens which is a capsule that contains oval and dark-brown seeds, each $035 \times 0.25 \mathrm{~mm}$ in size. When ripening, the leaves of capsule open, and the seeds spill out. One capsule may contain up to 2.000 seeds. A single broomrape plant may produce 200.000 or more tiny seeds most of which can persist in the soil for 10 years, or longer [10]. Wind, water, agricultural machinery, tillage tools, and vehicles easily spread broomrape seeds.

Such a high potential of the reproductive function of $O$. cumana and the frequent return of sunflower to its former field accelerate the emergence and rapid spread of new, more virulent parasite races that quickly overcome the resistance of new hybrids and varieties of sunflower. With frequent return of sunflower to its former field, the concentration of broomrape seeds in the arable layer of the soil increases disastrously. Under the current conditions, breeders do not have time to develop new sunflower genotypes that are resistant to new broomrape races. To solve the problem of broomrape control and to improve the phytosanitary condition of foul fields, an integrated approach to controlling this parasite is necessary.

It is necessary not only to cultivate sunflower genotypes, that are resistant to new virulent broomrape races, but also to comply with the crop cultivation technology, to apply the herbicides that kill the parasite without harming the sunflower plants, and to use the trap plants in crop rotations (corn, sorghum, millet, and Sudan grass) [11-14]. Compared with the herbicides application, the use of trap crops is more preferable as an environmentally safe way to clear fields from broomrape seeds.

Another environmentally safe method is noteworthy. As our observations show, cruciferous oil crops used as a green fertilizer can also help to suppress the germination of broomrape seeds. In 2016, we noticed a decrease in the sunflower broomrape infection at the farms in which white mustard (Sinapis alba L.) was grown on a field as a previous crop and its green mass (green manure) was crushed and plowed into the soil as a green fertilizer.

It is known that cruciferous oil crops can have a fatal rhizospheric effect on a couch grass (Elytrigia repens L.), causing vessels occlusion of its rhizomes by metabolic products. The application of green fertilizers into the soil and their plowing into the seed area of sown crops negatively affects their germination. The fresh plant residues usually contain inhibitors of germination and growth; therefore, after their plowing into the soil, it is necessary to wait some time for the decomposition by microorganisms. Crushed and plowed into the soil green mass of cruciferous oil crops inhibits the growth of red-root amaranth (Amaránthu sretrofléxus L.), shepherd's purse (Capsella bursa-pastoris L.), green foxtail (Setaria viridis L.), black nightshade (Solanum nigrum L.), and cockspur grass (Echinóchloa crus-gálli L.) [15]. Apparently, the green mass of cruciferous oil crops can have a similar effect on broomrape (O. cumana).

The suppression of weeds during the cultivation of cruciferous oil crops occurs under the influence of thiocyanins, sulfur-containing compounds obtained during decomposition of glucosinolates [16]. Glucosinolates are biologically active substances found in the leaves, stems, seeds, roots and root exudations of plants of the cruciferous family. Once in 
the soil, they inhibit the germination of seeds and the growth of the vegetative organs of weeds (biofumigation) [16].

The application of green fertilizer of oil cruciferous crops in the seed fallows and intermediate sowings contributes to the soil improvement as well as to the increase of the crop yields. The low costs of cultivation and the subsequent plowing of green mass into the soil make green manuring practice economically advantageous and deserving more attention from agricultural producers. The application of oil cruciferous crops in crop rotation as a green fertilizer could also contribute to the improvement of the phytosanitary condition of the fields infested with broomrape seeds.

The aim of our research was to study the effect of green manure of oil cruciferous crops on the infestation of sunflower with broomrape under the controlled greenhouse conditions.

\section{Materials and methods}

To develop an infectious background, we used the seeds of broomrape population $(O$. cumana) collected in 2017 in the Morozovsky district of the Rostov region.

To obtain green mass, we grew mustard and rapeseed plants in vessels until the phase of budding - the beginning of flowering.

The green mass of white mustard (Sinapis alba L.) - variety Ruslana, black mustard (Brassica nigra L.) - variety Niagara, common mustard (Brassica juncea L.) - variety Yunona and rapeseed (Brassica napus L.) - variety Tavrion was used as green manure. We grew the plants of these crops for 20 days and then crushed them to a size of $1 \times 1 \mathrm{~cm}$. We applied the green mass of plants, crushed together with the roots (from 62.5 to $90 \mathrm{~g}$ ), into the vessels with a mixture of sieved soil and sand in a ratio of 3:1 and the broomrape seeds at the rate of $200 \mathrm{mg}$ per $1 \mathrm{~kg}$ of soil-sand mixture. The surface area of the growing medium in each vessel was $0.04 \mathrm{~m}^{2}$. The green mass weight from 62.5 to $90 \mathrm{~g}$, applied to such area, is comparable with the average green mass yield of these crops, respectively from 15.6 to $22.5 \mathrm{t} / \mathrm{ha}$, which is plowed into the soil during green manuring. Tocreatefavorableconditionsand accelerate microbiological processes, we moistened the growing medium with plowed green mass on a regular basis for 15 days.

After 15 days, during which the microorganisms decomposed the crushed parts of mustard and rapeseed, we sow the seeds of sunflower variety VNIIMK 8883 susceptible to all races of broomrape by 10 pieces in each vessel,in 2 replications in all variants of the experiment. In the control, we did not apply green manure. We grew the sunflower plants in a greenhouse for 45 days at a 16 -hour photoperiod and at a temperature of $25-27^{\circ} \mathrm{C}$. Then, we dug the plants up and counted broomrape tubercles and shoots on the roots washed with water.

\section{Results and Discussion}

The degree of infestation of sunflower plants of variety VNIIMK 8883 with broomrape from the population of Morozovsky district of the Rostov region in the control variant was very high.

The average number of tubercles and shoots of $O$. cumana was 99 pieces per affected plant (Table 1). Usually, such severe infection leads to the harvest failure of crop, especially in areas with insufficient moistening. We revealed significant differences in the degree of plant infection by broomrape in the variants with applied green manure, in comparison with the control at a $5 \%$ significance level.

White mustard deserves special attention among the cruciferous family used for green manuring. The green manure of white mustard has prominent phytosanitary properties; it 
also helps to increase the microbiological activity of the soil and the accumulation of nutrients in it and to increase the yield of subsequent crop rotations.

Ruslana is a non-erucic variety of white mustard; it has a high seed yield potential, high initial growth rates, it is an excellent green fertilizer. The yield of green mass is $25 \mathrm{t} / \mathrm{ha}$. The green manure of white mustard Ruslana showed the highest percentage of decrease in the infection degree of sunflower variety $-44.7 \%$, under application of $71.3 \mathrm{~g}$ per $6.7 \mathrm{~kg}$ of soil-sand mixture. Such amount of plant biomass, applied into one vessel is comparable with the average yield of green mass of white mustard $-17.7 \mathrm{t} / \mathrm{ha}$, which is plowed into the soil during green manuring (Table 1).

Common mustard of variety Yunona is recommended for cultivation as a high-protein fodder additive and green manure. The harvest of its green mass can reach $33 \mathrm{t} / \mathrm{ha}$. The green manure of common mustard reduced the infection degree of sunflower variety VNIIMK 8883 by $25.9 \%$ (Table 1 ).

Table 1. The influence of green mass of oil crops from the family Brassicaceae on the degree of broomrape infestation of sunflower plants (variety VNIIMK 8883)

\begin{tabular}{|c|c|c|c|c|c|}
\hline Treatment & $\begin{array}{c}\text { Quantity of } \\
\text { soil per one } \\
\text { vessel, kg }\end{array}$ & $\begin{array}{c}\text { Broomrape } \\
\text { seeds added } \\
\text { per one } \\
\text { vessel, g }\end{array}$ & $\begin{array}{c}\text { Green mass } \\
\text { added per } \\
\text { one vessel, g }\end{array}$ & $\begin{array}{c}\text { The degree of } \\
\text { broomrape } \\
\text { infestation } \\
\text { pieces }\end{array}$ & $\begin{array}{c}\text { The decrease } \\
\text { of degree } \\
\text { infestation, } \\
\%\end{array}$ \\
\hline $\begin{array}{c}\text { Control } \\
\text { (without green } \\
\text { manure) }\end{array}$ & 6.3 & 1.7 & 0.0 & 98.8 & 0.0 \\
\hline $\begin{array}{c}\text { White mustard, } \\
\text { variety Ruslana }\end{array}$ & 6.7 & 1.8 & 71.3 & 54.6 & 44.7 \\
\hline $\begin{array}{c}\text { Common } \\
\text { mustard, } \\
\text { variety Yunona }\end{array}$ & 7.2 & 1.9 & 62.5 & 73.2 & 25.9 \\
\hline $\begin{array}{l}\text { Black mustard, } \\
\text { variety Niagara }\end{array}$ & 7.1 & 1.9 & 71.4 & 72.1 & 27.0 \\
\hline $\begin{array}{c}\text { Rapeseed, } \\
\text { variety Tavrion }\end{array}$ & 6.4 & 1.7 & 90.0 & 74.9 & 24.2 \\
\hline $\begin{array}{l}5 \% \text { significance level } \\
\text { \%he degree of broomrape infestation - is the quantity of tubercles and shoots per one } \\
\text { sunflower plant }\end{array}$ &
\end{tabular}

Niagara is the first black mustard variety in domestic production, it has the highest content of essential oil in the seeds $-1.0-1.1 \%$, and it is a source of allyl isothiocyanates (natural preservative). The green manure of black mustard reduced the sunflower infection in our experiment by $27.0 \%$, which is slightly higher than the indicator of common mustard.

Highly productive early-ripening variety of spring rapeseed Tavrion is stress-tolerant, and adapted for cultivation in various soil and climatic conditions. When we applied $90 \mathrm{~g}$ of spring rapeseed green mass per $6.4 \mathrm{~kg}$ of soil-sand mixture, the decrease in sunflower infection was only $24.2 \%$ (Table 1 ).

Presumably, in comparison with common mustard, black mustard and rapeseed, the white mustard biomass exudes a greater amount of specific substances in the process of decomposition and mineralization that inhibit the germination of $O$. cumana seeds.

Earlier, we conducted laboratory experiments by treating broomrape seeds with different concentrations of extracts from the green mass of common mustard. The experiments showed inhibition of both seed germination and the growth of O.cumana 
seedling, which should penetrate the sunflower root (Fig. 1). The soaking of $O$. cumana seeds for 10 days in a $100 \%$ extract of the cell sap of common mustard plants led to loss of their germination.

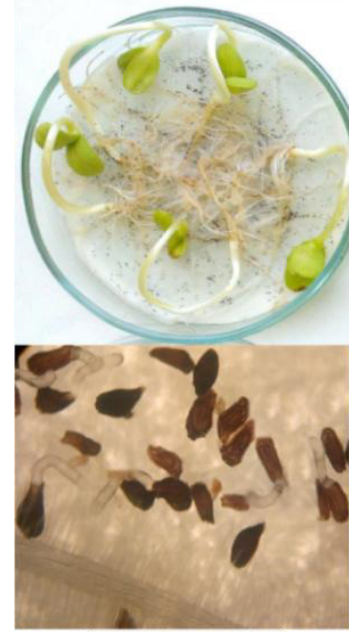

Control (water)
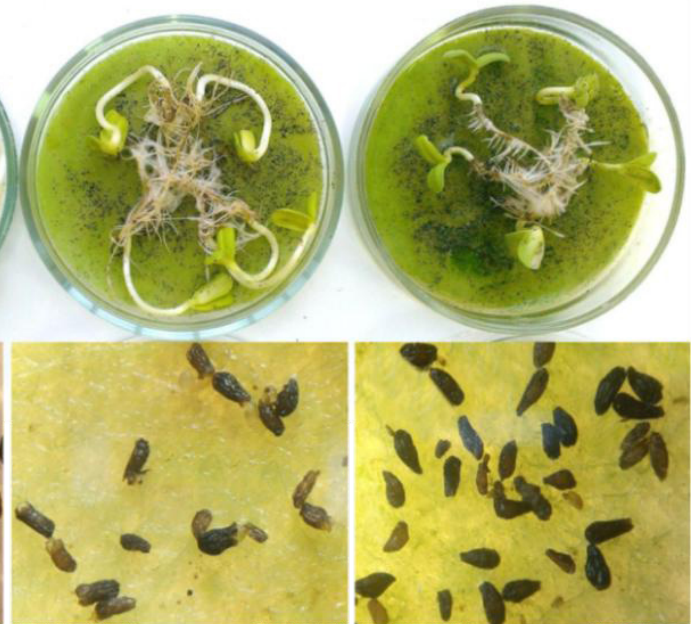

$25 \% \mathrm{CS}$

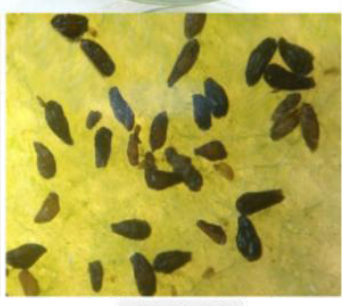

$50 \%$ CS

Fig. 1. The effect of different concentrations of cell sap (CS) of plants of common mustard variety on the germination of $O$. cumana seeds in the presence of roots of sunflower variety VNIIMK 8883(orig.)

Economically speaking, the relatively low cost of resources for cultivating and subsequent plowing of green mass of oil cruciferous crops into the soil to reduce the infection degree of sunflower with broomrape makes the green manure method accessible and deserving consideration of agricultural producers.

\section{Conclusion}

Thus, the experiment conducted under controlled greenhouse conditions showed a significant decrease in the sunflower plants infection with broomrape under presowing application of the crushed green mass of white, black, common mustard and winter rapeseed. Varieties of mustard (white, black, and common) and rapeseed are approved for production in the regions of the Russian Federation. We recommend using green manures of these oil cruciferous crops to reduce the infection of sunflower crops with broomrape and as an environmentally safe way to clear fields from broomrape seeds in combination with already known control methods.

\section{References}

1. T.S. Antonova, N.M. Araslanova, E.A. Strelnikov, S.A. Ramazanova, S.Z. Guchetl, T.A. Tchelyustnikova, Proceedings 18th International Sunflower Conference. MAR Del Plata \& Balcarce - Argentina, February 27 - March 1, 1025-1030, (2012)

2. M. Amri, Z Abbes, S. Ben Youssef, M. Bouhadida, H. Ben Salah, M. Kharrat, Afr. J. Biotechnol 11(18), 4163-4167, (2012)

3. O. Shindrova, and E. Penchev, Helia, 35(57), 87-94 (2012) 
4. M.L Molinero-Ruiz, A.B García-Carneros, M.Collado-Romero, S. Raranciuc, J. Domínguez, J.M. Melero-Vara, Weed Res 54, 87-96 (2014) http://dx.doi.org/10.1111/wre.12056

5. M. Pacureanu, Proc. 3rd Int. Symp. on Broomrape (Orobanche spp.) in Sunflower, Córdoba, Spain, 39-43 (2014)

6. D.T. Ma, C.C. Jan, Proc. 3rd Int. Symp. on Broomrape (Orobanche spp.) in Sunflower, Córdoba, Spain, 65-69 (2014)

7. B.X. Shi, G.H. Chen, Z.J. Zhang, J.J. Hao, L. Jing, H.Y. Zhou, J. Zhao, Plant Dis. 99: 291 (2015) http://dx.doi.org/10.1094/PDIS-07-14- 0721-PDN

8. Ya. Kaya, Proc. 3rd Int. Symp. on Broomrape (Orobanche spp.) in Sunflower, Cordoba, Spain, 9-18 (2014)

9. T.S. Antonova, N.M. Araslanova, E.A. Strelnikov, S.A. Ramazanova, S.Z. Guchetl, T.A. Tchelyustnikova, Helia, 35(56), 99-110 (2012) https://doi.org/10.2298/HEL1256099A

10. T.S. Antonova, S. Masirevic, R. Harveson In: R.M. Harveson, S.G. Markell, C.C. Block, T.J. Gulya (eds.) Compendium of Sunflower Diseases and Pests. The American Phytopathological Society. St. Paul., Minnesota, U.S.A. 23-25 ( 2016)

11.D.M. Joel, In: Chapter 8, Parasitic Orobanchaceae, Parasitic Mechanisms and Control Strategies. D.M. Joel; J. Gressel and L.J. Musselman, editors. Springer Heidelberg, New York Dordrecht London. 143-146 (2013)

12. Y. Goldwasser and J. Rodenburg, In: Chapter 22, Parasitic Orobanchaceae, Parasitic Mechanisms and Control Strategies. D.M. Joel; J. Gressel and L.J. Musselman, editors. Springer Heidelberg, New York Dordrecht London. 393-413 (2013)

13. Leire Molinero-Ruiz, Philippe Delavault, Begoña Pérez-Vich, Maria PacureanuJoita, Mariano Bulos, Emiliano Altieri and Juan Domínguez, Spanish J. of Agricultural Research 13(4), e10R01, 19 (2015) http://dx.doi.org/10.5424/sjar/2015134-8080

14. T.S. Antonova, L.C. Alonso, E.A. Strelnikov, N.M. Araslanova, Russian J. of Agricultural Sciences, 41, 5, 347-351 (2015) https://doi.org/10.3103/S1068367415050031

15. Ahmed SAA, Nadia K. Messiha; Kowthar, G. El-Rokiek, Sanaa, A. Mohamed and El-Masry RR.,RJPBCS), 7 (5), 158-165 (2016)

16. Franziska S. Hanschen, Yim Bunlong, Traud Winkelmann, Kornelia Smalla, Monika Schreiner, July 17, 1-18 (2015) Plos one | DOI:10.1371/journal.pone.0132931 